\title{
Issues at the Rural-Urban Fringe: Land Use -- Agricultural Zoning ${ }^{1}$
}

Rodney L. Clouser ${ }^{2}$

\section{Introduction}

This fact sheet is one in a series intended to familiarize readers with land use issues at the rural-urban fringe. The next several fact sheets specifically address techniques used in various states, including Florida, to encourage the long-term stability of land in agricultural production. Many states use more than one technique in an attempt to prevent land from converting from agricultural to non-agricultural use. Future fact sheets will explicitly address techniques of Agricultural Districts, Fee Simple Purchase and Purchase of Development Rights, Transfer of Development Rights, Clustering of Development, and Conservation Easements.

\section{Definition}

What is zoning-and more specifically, what is agricultural zoning? Zoning is a land use regulation which typically places constraints on the type and intensity of land use and land development (Kruft, 2001). Zoning is accomplished within political jurisdictions by dividing land within a jurisdiction into "districts" (Mulkey and Clouser, 1987). Land and building use within districts are regulated and consistent, but there can be many districts within a political jurisdiction and regulations among districts can vary substantially. Agricultural zoning is a specialized form of zoning where the type and intensity of land use and land development is compatible and consistent with food and fiber production. Agricultural zones are typically adopted in areas interested in protecting, stabilizing, or preserving the agricultural land base and, at the same time, keeping individuals employed in the production of food and fiber crops.

\section{History and Background}

Zoning was validated by the U.S. Supreme Court in 1926 (q.v., Village of Euclid v. Amber Realty Co., 272 U.S. 365) as a means of determining how a piece of land might be used other than allocation of use by individual property rights (Mulkey and Clouser, 1987; Hudkins, n.d.; Kruft, 2001). The legal basis for zoning rests in the police powers of local governments to protect the health, safety, morals, and general welfare of local citizens. Agricultural zoning is a general extension of these protections to land and citizens in rural areas. Zoning has been used

1. This is EDIS document FE554, a publication of the Department of Food and Resource Economics, Florida Cooperative Extension Service, Institute of Food and Agricultural Sciences, University of Florida, Gainesville, FL. This document is one of a series entitled "Issues at the Rural-Urban Fringe". Published May 2005. Please visit the EDIS website at http://edis.ifas.ufl.edu.

2. Rodney L. Clouser, Professor and Public Policy Specialist, Department of Food and Resource Economics, Florida Cooperative Extension Service, Institute of Food and Agricultural Sciences, University of Florida, Gainesville, FL. 
successfully for many years in urban and suburban areas as an effective mechanism to avoid land use conflicts. For example, homes are separated from factories, factories usually are separated from schools and day care centers, and facilities that serve alcohol are often separated from churches, schools, homes, etc.

All U.S. states have legislation enabling zoning. In the mid 1980s, it was estimated that 22 states used agricultural zoning. Early state adaptors of agricultural zoning in the 1970s included rural counties in California, Washington, and Pennsylvania. The National Agricultural Lands Study reported 270 counties were using agricultural zoning by 1981 . In a 1995 informal study by the American Farmland Trust (AFT), about 700 local governments in 24 states had enacted some form of Agricultural Protection Zoning (APZ). The APZ definition used by American Farmland Trust is relatively restrictive and requires a limit of no more than one house per twenty acres and places restrictions on non-farm land use. Using this definition means that more than 700 units probably use agricultural zoning but do not meet the restrictive definition of AFT.

A summary of motives for adopting agricultural zoning programs typically includes protecting farmland, preventing land conflicts between farms and non-farm development, reducing public costs for infrastructure by encouraging more compact urban development, protecting agriculture's economic base, and addressing environmental concerns (Mulkey and Clouser, 1987). Other motives for adopting agricultural zoning programs include attempts to keep farm land prices reasonable (Hudkins, n.d.) and protecting prime or unique agricultural soils (Kruft, 2001).

\section{Types of Zoning Programs}

There are two general types of agricultural zoning: exclusive and nonexclusive. The more widely used and least restrictive is nonexclusive agricultural zoning. Nonexclusive agricultural zoning recognizes agriculture production as the preferred use in certain areas but does not prohibit other land uses in the agriculturally zoned area. Non-farm uses of land are typically allowed and the conversion of farmland to non-farm use is allowed if approved by a local zoning agency. Nonexclusive agriculture zones typically limit population density, large lot sizes are often required for residential units, and nonagricultural land use usually must be compatible with agriculture production. Compatible uses include livestock feed stores, farm implement dealers, and retail nurseries and greenhouses as examples. Minimum lot sizes are usually in the one to five acre range but can be much larger. For example, in Florida, Lake County will approve agricultural lot splits with a minimum of 40 acres and the lot split must include five acres of uplands, while in other states, minimum lot sizes of 50 acres have been used in Pennsylvania, 160 acres in Illinois (Delogu, 2002) and 640 acres in some western states (Delogu, 2002; American Farmland Trust, 1998). The theory surrounding larger lot sizes is that they should represent the minimum sized land base needed for sustainable agriculture production.

Exclusive agricultural zoning is much more restrictive. Usually non-farm residences, non-agriculture activities, and retail businesses are prohibited. Of course, in some instances exceptions are granted after appropriate local review. Examples might be roadside farm sales from producing farms or nursery retail sales from producing nurseries within the agricultural zone. In some instances, other uses are allowed in exclusive agricultural zones, such as cemeteries, landfills, schools, churches, animal hospitals, etc., which can be placed on lower quality land but also provide services to the agricultural community.

\section{Policy Considerations}

Several policy questions must be considered and evaluated with respect to agricultural zoning programs. In some instances, agricultural zoning may be an inexpensive method for sustaining agricultural land use. However, in exclusive agricultural zones, it may be an expensive way to sustain agricultural production. This occurs because any land use change requires individualized review before acceptance or rejection. The same would hold true for any new construction in an exclusive zone. In combination, staff costs (county-based staff) for review of proposed changes coupled with consultants for the landowner, such as legal consulting, could result in rapidly escalating costs. 
Exclusive zoning programs may be more successful than other programs in sustaining large blocks of agricultural land. This occurs because an entire area, usually engulfing hundreds if not thousands of acres, is set aside for farming activities where other land-use programs base decisions on a parcel-by-parcel basis. Exclusive zones should have a better success rate in reducing farm versus non-farm complaints than do nonexclusive agricultural zones due to the strict limits placed on land use and new construction. Some even argue that exclusive agricultural zones limit urban sprawl by limiting extension of infrastructure such as water, sewer, road expansion, etc. in the exclusive zone.

All zoning programs are likely to be of concern to landowners due to potential impacts on land values. By eliminating or reducing speculative development value on agricultural lands, the market value (arm's-length transaction between a willing buyer and seller) is often reduced. For the owner, this results in a loss of equity in the farm land asset and could create opposition to zoning programs. Greater opposition to exclusive zoning programs would be expected since the equity value in land assets would be larger and the equity reduction bigger.

Zoning programs are also subject to legal challenges based on fairness concepts, the burden of land preservation being placed on the landowner through reduced values, and long-term community-wide development impacts and implications (Cordes, 2001). Zoning programs are also not unending; they can be eliminated by a majority vote of elected decision makers (e.g., county commissioners and supervisors) at any time. This instability could be a concern in many communities. In many areas agricultural zones do not prohibit areas or entire zones from being annexed by municipal governments (American Farmland Trust, 1998).

Despite these policy considerations, one certainty is known about zoning-local government has long used this approach with other classes of property. The advantages and disadvantages of zoning are well-known by governmental units. Prior experiences with zoning should result in fewer implementation concerns if applied to agricultural zoning.

\section{References}

American Farmland Trust. 1998. Agricultural Protection Zoning. American Farmland Trust, Washington, D.C. http://www.farmlandinfo.org/documents/29478/ FS_APZ_9-98.pdf.

Cordes, Mark W. 2001. Agricultural Zoning: Impacts and Future Directions. Proceedings of the Protecting Farmland at The Fringe: Do Regulations Work? Conference. Baltimore, MD (September). http://www.farmfoundation.org/projects/01-47.pdf.

Delogu, Orlando. 2002. Passive Resistance to the United States Supreme Court's Takings Jurisrudence:

A Growing and Ominous Trend. Annual Land Use Conference. Rocky Mountain Land Institute, Snowmass, CO (March). http://www.law.du.edu/rmlui/HotTopics/Takings/ Delogu2002PassiveResistanceUSSC'sTakingsJurispr udence.htm.

Hudkins, Stephen J. n.d. Agricultural Zoning. OSU Extension Fact Sheet CDFS-1266-69. The Ohio State University, Columbus, $\mathrm{OH}$. http://ohioline.osu.edu/cd-fact/1266.html.

Kruft, David. 2001. Agricultural Zoning. Dickinson School of Law, The Pennsylvania State University, State College, PA.

http://www.dsl.psu.edu/centers/aglawpubs/ zoning.cfm.

Lake County, Florida. n.d. Agricultural Lot Splits. http://www.lakegovernment.com/departments/ growth_management/zoning_and_customer_service/ lot_splits.

Mulkey, David, and Rodney L. Clouser. 1987. Maintaining Land for Agriculture. FRE-29. Department of Food and Resource Economics, University of Florida, Gainesville, FL. 